\title{
ORTODOKSJA I HEREZJA W RELACJACH LUDZI I ZWIERZĄT
}

\author{
Anna Dietl \\ Uniwersytet Warszawski
}

\section{/// Społeczna kreacja świata ludzi i zwierząt}

Patrząc na to, jak rozmaicie postrzegano i traktowano te same gatunki zwierząt na przestrzeni dziejów w różnych rejonach świata, można uświadomić sobie, w jak dużym stopniu obraz zwierząt jest konstruktem społecznym. Weźmy za przykład psa postrzeganego jako członek rodziny, zwierzę domowe, opiekun, stróż, pasterz, przewodnik, ratownik, zwierzę zaprzęgowe, zwierzę nieczyste, a nawet pożywienie (Pręgowski 2016: 1-9).

Relacja ludzi i zwierząt warta jest analizy socjologicznej, ponieważ znajduje się obecnie w fazie intensywnych społecznych przemian. Współcześnie w świecie zachodnim, w tym także w Polsce, te relacje są redefiniowane przede wszystkim w kierunku zakwestionowania uprzednio dominującego podejścia antropocentrycznego. Choć trudno mówić o jednolitości w aspekcie filozoficznym, odchodzenie od antropocentryzmu i antropomorfizacja zwierząt są coraz bardziej widoczne i zyskują społeczne uprawomocnienie, między innymi dzięki mediom. Zwierzętom, a właściwie zmianie nastawienia do zwierząt, poświęcane są audycje radiowe i telewizyjne, liczne publikacje książkowe i prasowe, artykuły, wywiady i kampanie społeczne. Skalę zjawiska przybliża m.in Raport medialny „Problematyka zwierzat w polskich mediach" (Press Service Monitoring Mediów 2018).

Siła medialnego przekazu, jego współczesna wszechobecność i nieustanność wzmacniana jest dodatkowo autorytetem nauki. „Pojawia się 
niezwykła sytuacja epistemologiczna, gdy wiedza sama zdolna jest zmienić swój własny przedmiot" (Sztompka 2008: 16). Ta refleksyjność wiedzy o relacjach ludzi i zwierząt jest wyraźnie obecna także ze względu na jawne zaangażowanie części naukowców w zmianę etyczną (i epistemologiczną) względem zwierząt. Odbiorcami nauki w tym obszarze nie są jedynie inni naukowcy, ale przede wszystkim szerokie kręgi społeczne, a jej celem jest nie tylko poznanie, lecz także jawnie wyrażana zmiana społeczna. Efektem takiego działania jest ogromna liczba publikacji popularyzatorskich, w których autorzy przekładaja hermetyczny język nauki na bardziej potoczny, ale zarazem modyfikujący przyjęte sposoby opisywania świata. Przykładem takiego funkcjonowania języka jest używanie w mediach i publikacjach naukowych sformułowania „ludzie i inne zwierzęta” czy „zwierzęta w tym ludzie”, co przekształca kategorie „my ludzie” kontra „zwierzęta” we wspólną kategorię „my zwierzęta” (Grabowska 2016: 36).

Analiza relacji ludzi i zwierząt pozwala dostrzec i docenić wagę faktu, że opisane powyżej zjawisko nie jest na tyle powszechne, by można było obecnie mówić o jednoznacznym zastapieniu postawy antropocentrycznej. Przeciwstawne paradygmaty dotyczące właściwego sposobu postrzegania zwierząt i kształtowania relacji ludzko-zwierzęcych funkcjonują równolegle. Trend związany z „docenieniem osób nieludzkich” funkcjonuje równolegle $z$ akceptacją wykorzystywania zwierząt na dotychczas niespotykaną skalę.

Z jednej strony mamy ujęcia zoopersonalistyczne - analizy wskazujące na zajmowanie istotnych miejsc w rodzinach ludzkich (Konecki 2005), zagadnienie adopcji, godnej śmierci, obszar praw zwierząt i niezgody na ich uprzedmiotowione traktowanie - wręcz holokaust (Mamzer 2017: 163178). Z drugiej - zwierzęta sa przedstawiane jako istotny sektor gospodarczy albo mięso przeliczane na tony. Są katalogowane poprzez chipowanie, tatuowanie, wypalanie czy wymrażanie numerów na ciałach, a także rozmnażane i modyfikowane genetycznie dla przyjemności albo pożytku człowieka. Stanowią źródło utrzymania człowieka i pełnią wobec niego najrozmaitsze funkcje służebne. Złożony i niekonsekwentny stosunek do zwierząt, zarówno w perspektywie ogólnospołecznej, jak i indywidualnej, portretuje m.in. książka pod znamiennym tytułem Some We Love, Some We Hate, Some We Eat (Herzog 2011). 


\section{/// Cele i założenia metodologiczne analizy}

Inspiracją do powstania tego artykułu były pytania: jaki wpływ na postrzeganie przez ludzi zwierząt ma medialna kreacja zwierzęcego wizerunku? oraz jakie są wzajemne odniesienia poszczególnych nurtów narracji medialnej? Cel poniższego artykułu jest podwójny - teoretyczny i empiryczny. W warstwie teoretycznej pokazuję, jak teologiczne kategorie herezji i ortodoksji można wykorzystać do socjologicznej analizy zjawisk społecznych poza obszarem teologii. W warstwie empirycznej na podstawie wybranego materiału prasowego wskazuję istotne nurty dyskursu relacji ludzi i zwierząt, a następnie porównuję te nurty, wykorzystując pojęcia herezji i ortodoksji.

Moja ambicja nie jest opisanie całego dyskursu dotyczącego ludzi i zwierząt, gdyż jest on niezwykle rozległy i krzyżuje się z innymi, w tym z dyskursem ekologicznym, klimatycznym, szeroko ujętym dyskursem posthumanizmu (por. Rejter 2016: 21-30) czy dyskursami wykluczenia społecznego. Co więcej, każda analiza dyskursu, w tym poniższa, jest jednocześnie uczestnictwem w nim, co wpływa na jego przebieg. Dlatego też taka analiza pozostaje zawsze do pewnego stopnia niedomknięta. Dzięki pracy na wybranym materiale prasowym chcę natomiast wykazać przydatność teologicznych kategorii herezji i ortodoksji, które dzięki wpisanej w nie relacyjności wzbogacaja sposoby analizy socjologicznej.

Odwołując się do pojęcia dyskursu, mam świadomość, że słowo to w literaturze używane jest w różnych zakresach: od pojedynczej wypowiedzi aż do synonimu systemu społecznego (Howarth 2008: 14). Mówiąc o użyciu języka, często włącza się w obszar tego pojęcia zarówno tekst mówiony, jak i pisany, a także przekaz wizualny oraz związane z nimi formy komunikacji. W takim ujęciu poniższa analiza prasowa relacji ludzi i zwierząt jest wycinkiem większego dyskursu zdefiniowanego tematycznie ze względu na swój „przedmiot badawczy” (Pawliszak, Rancew-Sikora 2012: 5-18). Filozoficznie lokuję swoje rozważania w tradycji Michaela Foucaulta, który „w społecznych dyskursach i regułach ich formowania widzi komunikacyjne narzędzia zazwyczaj niejawnego panowania" (Czyżewski 2013: 11), czyli skupia się na relacjach wiedzy, władzy i dominacji.

Odwołując się do dyskursu herezjologicznego, koncentruję się nie tyle na samych herezjach, ile na chrześcijańskiej herezjologii, czyli dyskursie ortodoksji i herezji rozumianym jako sposób definiowania tego, co było uznawane za ortodoksję, a co za herezję (Jorgensen 2017: 5). Interesuje mnie zatem bogactwo znaczeń samych pojęć oraz dynamiczny proces 
uznawania danych przekonań za ortodoksyjne lub heretyckie. Uwaga nakierowana jest tu na historię dyskursu herezji i ortodoksji, a zwłaszcza na tzw. „reprezentacje herezjologiczne”, czyli sposoby przedstawiania siebie i własnej doktryny jako ortodoksji, a oponentów i głoszonych przez nich doktryn - jako heretyków i herezji (tamże).

Prześledzenie dyskursu herezjologicznego wydobywa istotne wymiary, które można wykorzystać w analizie zjawisk socjologicznych nieodnoszących się bezpośrednio do doktryny religijnej lub też znajdujących się na jej obrzeżach, tak jak to się dzieje z zagadnieniami zwiąanymi z relacjami ludzi i zwierząt. Pozwala też, co uważam za szczególnie istotne, pogłębić analizę współwystępowania sprzecznych poglądów o aspekty ich wzajemnych odniesień oraz dynamiczny proces uznawania ich za prawdziwe lub fałszywe, czyli zdobywania przez nie pozycji dominującej.

\section{/// Kryteria doboru materiału analitycznego}

Na potrzeby analizy relacji ludzi i zwierzat, z uwzględnieniem perspektywy wymiarów, jakie niosa ze soba pojęcia herezji i ortodoksji, wybrałam próbkę czterech czasopism opiniotwórczych, z których dwa tworzą jedną grupę. Sa to: Życiowa madrość zwierzat, „Newsweek Polska. Nauka o zwierzętach” (nr 1/2018) oraz Życie uczuciowe, „Newsweek Polska. Extra o zwierzętach” (nr 3/2017), Zwierzenia Zwierzqt, „Tygodnik Powszechny. Wydanie Specjalne” (nr 3(11)/2019) oraz Zwierze, Zwierze ponad wszystko!, „Polonia Christiana" (nr 71/2019).

Świadomie pominęłam wydawnictwa poświęcone konkretnie tematyce zwierzat, ich hodowli (gospodarczej, kynologicznej czy hobbystycznej), problemom weterynarii, myślistwu czy podobnym. Sięgnęłam po czasopisma, dla których podjęcie kwestii człowiek-zwierzę wykracza poza podstawową tematykę i jest skutkiem celowego wyboru redakcji. Dokonując selekcji, uwzględniłam jeszcze dalsze kryteria:

1. Podjęcie tematu relacji ludzi i zwierząt jako istotnego społecznie problemu: analizowane czasopismo stanowi wydanie specjalne, dodatek tematyczny lub też temat zwierząt potraktowano w nim jako temat numeru. Punktem wyjścia dla tego kryterium jest założenie, że podjęcie danego tematu przez ogólnopolskie drukowane czasopismo opiniotwórcze wiąże się z docenieniem jego istotności, zarówno merytorycznej, jak i oceny skali zjawiska.

2. Intencjonalność przekazu: publikacje zawarte w tych wydaniach wprost odnoszą się do właściwego sposobu kształtowania relacji 
ludzi i zwierząt. Jawnie nastawione są na kształtowanie poglądów i formowanie postaw odbiorców w społecznym sporze o stosunek do zwierząt (i postrzeganie ludzi w tym kontekście).

3. Światopoglądowe zróżnicowanie czasopism. Wybrane czasopisma reprezentuja opcje: laicką („Newsweek Polska”), katolicyzmu otwartego („Tygodnik Powszechny”) oraz strażnika tradycji („Polonia Christiana”). Mam świadomość zastosowania uproszczonego nazewnictwa określającego profil tych czasopism oraz faktu, że użyte określenia same są dyskursywne, uczestniczą i są ksztaltowane $\mathrm{w}$ intensywnie toczących się sporach społecznych. Już samo precyzyjne określenie tych opcji światopoglądowych zasługuje na oddzielną analizę. Dla mnie istotne jest ich zróżnicowanie, a co za tym idzie, potencjalnie przeciwstawne wzajemne odniesienia. Z tego też względu zdecydowałam się włączyć do analizy numer „Polonia Christiana”, mimo znacząco niższego nakładu wydawniczego.

\section{/// Dyskurs herezjologiczny (zarys) jako źródło inspiracji dla analizy socjologicznej}

Pierwotne pojęcie herezji jest wieloznaczne i w różnych okresach historycznych i kulturach było nieco odmiennie pojmowane. Źródłosłów słowa herezja (gr. hairesis) wskazuje na jego pochodzenie od słów „wzięcie sobie, wybór" (Latusek, red. 2008: 347). Pojęcie to wywodzi się z języka greckiego i początkowo niosło ze sobą wiele znaczeń i kontekstów związanych przede wszystkim z podejmowaniem pewnych wyborów, decyzji, formowaniem niezależnych prądów czy szkół filozoficznych. Samo pojęcie nie miało jednak jednoznacznie negatywnego znaczenia doktryny fałszywej, jakie wiąże się z późniejszą tradycją chrześcijańską (Vanhoutte 2019: 5). Współcześnie herezja ponownie może przyjmować kontekst pozytywny, odwołujący się do wolności myślenia, filozofowania, niezgody na bezkrytyczne przyjmowanie oficjalnej wersji rzeczywistości. Przykładem takiego podejścia na gruncie polskim jest książka Herezja znaczy wolność (Prokopiuk 2008).

Zestawienie współczesnych słownikowych znaczeń terminu berezja wskazuje przede wszystkim na relacyjny charakter tego pojęcia. Herezja jako odmienność, odstępstwo, zaprzeczenie potrzebuje punktu odniesienia, swojej ortodoksji, choć precyzyjne wskazanie, czym dokładnie jest 
i czego konkretnie dotyczy, nie jest bynajmniej jednoznaczne. Ta niejednoznaczność i kontekstowość ujawnia się już w zwykłej analizie słownikowej.

Definicja herezji jako „samowolnego i upartego odstępstwa osoby ochrzczonej od prawowiernej nauki wiary" (O’Collins, Farrugia, red. 2002: 56) przyjmuje waski zakres znaczenia, co sprawia, że sytuuje adwersarzy wewnątrz chrześcijaństwa i ogranicza kwestię odmienności poglądów do bezpośrednich wytycznych religijnych. Zgodnie z tą definicją herezja możemy nazwać tylko pogląd, który wyrażony jest przez osobę wewnątrz danej wspólnoty ochrzczonych, i tylko jeśli sprzeciwia się konkretnie nauce wiary. Jeszcze ściślej definiowana jest herezja jako „kacerstwo”, czyli zaprzeczanie oficjalnie uznanym przez Kościół dogmatom (Kaczorowski, red. 2006: 331). W takim rozumieniu nauka, wobec której wyrażany jest sprzeciw, przyjęta jest za prawdziwą formalnie, a zatem akcentowany jest dodatkowo ośrodek (i/lub osoba) akceptujący dany pogląd jako obowiązujący w ramach doktryny wiary.

Leszek Kołakowski zauważa, że gdy mówimy o herezji, kluczową kwestia jest przeciwstawienie sobie woli ludzkiej i woli Bożej.

Jeśli zważyć zepsucie naszej woli w wyniku grzechu pierworodnego, czysto ludzki wybór w sprawach wiary jest notorycznie wyborem na rzecz błędu, nie zaś aktem wybierania, który może być słuszny lub niesłuszny, zależnie od okoliczności. Z tego punktu widzenia wydaje się, że teologicznie słusznie byłoby powiedzieć, że z aktów wyboru ludzkiego w dziedzinie wiary nieuchronnie powstaje herezja; że więc herezja jest to doktryna wybrana czy też afirmowana przez wolę ludzką bez udziału Boga (Kołakowski 2010: 8-9).

Znamienne jest, że definicja Kościoła katolickiego odnosi się nie tyle do samej herezji, ile do osoby heretyka. Jako istotne wskazuje nie tylko negowanie czy powatpiewanie oraz uporczywe trwanie przy błędnym poglądzie, lecz także fakt bycia ochrzczonym oraz chęć bycia uznawanym za chrześcijanina. Herezja byłaby tu zatem kwestią wewnętrzną wspólnoty, a heretyk tym, który przegrał walkę o uznanie swojej interpretacji.

Heretyk [...] jest to zawsze ktoś, kto się odwołuje do tego samego kanonu, do tego samego źródła mądrości, do którego odwołuja się ortodoksi czy też zwierzchnicy Kościoła, ale interpretuje ten kanon w inny sposób. [...] Dlatego też sam bardzo często oskarża 
Kościół i ortodoksów, że oni właśnie są heretykami. Że ostatecznie on zostaje uznany za heretyka, a nie jego przeciwnicy, dzieje się przeważnie dlatego, że jest on po prostu pokonany albo jest w mniejszości, a ortodoksji udaje się utrzymywać bez zmiany ciągłość religijnej instytucji. Ci, którzy nigdy nie przyjmowali pierwotnego kanonu Objawienia, albo ci, którzy odrzucaja go w całości i wyraźnie, zamiast twierdzić tylko, że to oni wiedzą lepiej, jak ten kanon interpretować, są bądź poganami, bądź ateistami czy apostatami, ale nie heretykami (tamże: 11).

Odczytanie słowa „herezja” w jego znaczeniu przenośnym - ,idea, pogląd sprzeczny z utartymi, powszechnie przyjętymi w danym środowisku poglądami; odstępstwo od powszechnie przyjętego poglądu" (Sobol, red. 1995: 250) - uwalnia to pojęcie z kontekstu stricte religijnego, przyjmując perspektywę relacji uznana większość kontra nieakceptowana mniejszość. Same poglądy nie muszą stanowić uznanego i obowiązującego dogmatu, lecz mogą być po prostu poglądami rozumianymi same przez się, przyjmowanymi jako oczywiste, nie poddawanymi krytycznej refleksji.

Kolejną interesująca perspektywę analityczną niesie odwołanie się do herezji rozumianej jako „zawładnięcie czymś, [...] także utworzenie odrębnej wspólnoty" (Granat, red. 1973: 751). Wydobyty jest tu więziotwórczy i równocześnie sekciarski aspekt herezji, wskazujący nie tyle na odmienność poglądów, ile na odłączenie się od grupy pierwotnej.

Choć pojęcie herezji często zestawiane jest z pojęciem ortodoksji, wbrew potocznej intuicji nie jest pewne, które z tych zjawisk było pierwsze. Najstarsze, tradycyjne podejście można określić „nauką o pierwszeństwie ortodoksji, o pierwotnej czystości wiary" (Myszor 2003-2004: 133). Przez wieki (II-XX) dominowała opinia, że ortodoksja jako kanon prawdy w oczywisty sposób poprzedza herezję (Jorgensen 2017: 1). Jest to pogląd, który ma swoich zwolenników także obecnie (Köstenberger, Kruger 2010; Widok 2012: 15). Natomiast samo pojęcie ortodoksji jako wiedzy prawdziwej, w opozycji do błędnej, czyli herezji, pojawiło się w IV wieku (Widok 2012: 15).

Pogląd o pierwszeństwie ortodoksji względem herezji został zakwestionowany przez Waltera Bauera w 1934 roku. Starał się on uporać z uproszczonym utożsamianiem pojęć ortodoksji i herezji odpowiednio z większością lub mniejszością oraz równocześnie z definiowaniem herezji jako procesu pojawiania się błędnych założeń w miejsce prawdziwych poglądów (Harrington 1980: 289-298). Jego rekonstrukcja początków chrze- 
ścijaństwa wskazuje, że to, co nazywa się chrześcijańską ortodoksją, jest poglądem wspólnot związanych z ośrodkiem w Rzymie, których wpływ stopniowo się rozszerzał, obejmując także obszary, w których chrześcijaństwo zapoczątkowane zostało przez poglądy uznane post factum za heretyckie.

Pogląd Bauera został potwierdzony i spopularyzowany przez Barta Ehrmana, wskazującego, że stwierdzenie, czym jest ortodoksja i kiedy mamy z nią do czynienia, możliwe jest w pełni dopiero post factum, z perspektywy historycznej. W takiej perspektywie ortodoksja byłaby nie tyle konsekwencją kolejności pojawiania się poglądów czy ich niezmienności, ile faktem znalezienia się na wygranej pozycji (Jorgensen 2017: 4-5).

Choć dyskurs herezjologiczny ostatecznie nie doprowadził do uzgodnienia, jak wyglądały historyczne początki formowania się doktryny chrześcijańskiej i jak optymalnie je opisywać, z punktu widzenia moich analiz najistotniejszy jest fakt relacyjnego ujmowania herezji i ortodoksji „[...] Ortodoksja nie może poprzedzać herezji (tradycyjne podejście), ani też herezja poprzedzać ortodoksji (Bauer), ortodoksja i herezja musza, w sposób konieczny, wchodzić w świat dyskursu razem. Ortodoksja i herezja nie sa rzeczami, ale pojęciami, które zawsze muszą być definiowane we wzajemnym odniesieniu (Boyarin 2004, 3; cf. Berlinerblau, 2001, 330-332)"1 (Jorgensen 2017: 5).

Kolejnym elementem, na który chciałabym wskazać w tym krótkim zarysie dyskursu herezjologicznego, jest wpływ na ortodoksję tzw. herezji kontaktowej, czyli prądów myślowych zewnętrznych wobec pierwotnego zakresu doktryny. „Chrześcijanie przez kontakt z obcą formą religijności zaczynali tworzyć własne poglądy [...]. Gnostycy przez swoją obca dla chrześcijaństwa religijność zwrócili uwagę na pewne istotne dla chrześcijaństwa prawdy, sprowokowali polaryzację stanowisk w Kościele” (Myszor 2003-2004: 136-137). Zderzenie z taką zewnętrzną perspektywą w sposób pozytywny (włączanie nowych myśli) i negatywny (odcinanie się od poglądów) prowadziło do poszerzania i krystalizacji ortodoksji (tamże: 136).

Poruszone powyżej wątki dyskursu herezjologicznego koncentrują się na wzajemnych odniesieniach przeciwstawnych przekonań. Natomiast na całość wiary składały się nie tylko poglądy, czyli ortodoksja, lecz także praktyki religijne, czyli ortopraksja. „Życie religijne nie wymaga ostro i wy-

\footnotetext{
1 „Orthodoxy cannot precede heresy (the traditional account), nor can heresy precede orthodoxy (Bauer); orthodoxy and heresy must, of necessity, come into the world of discourse together. Orthodoxy and heresy are decidedly not things, but notions that must always be defined in each other's context" (tłum. aut.).
} 
raźnie zarysowanych poglądów, wymaga jedynie odwołania do prawdy wyznawanej bardziej czynem niż słowem" (tamże: 135). Analogicznie także w pozareligijnych obszarach życia działania wyrażaja posiadane przekonania, nawet jeśli te są nie do końca uświadomione i sprecyzowane.

Podsumowując: analiza dyskursu herezjologicznego wskazuje elementy warte rozważenia w analizie relacji ludzi i zwierząt. Są to zatem:

- rozpatrywanie poszczególnych narracji we wzajemnych odniesieniach zgodnie $z$ modelem ortodoksja-herezja,

- zarysowana perspektywa czasowa - które poglądy prezentowane są jako historycznie pierwsze i jakie znaczenie się temu przypisuje,

- stopień jednoznaczności i definitywności formułowanych przekonań,

- rozróżnienie herezji jako nieprawdziwych poglądów oraz heretyka jako osoby stawianej poza nawiasem wspólnoty,

- określenie, które poglądy niezgodne z własną opcją sytuowane są w ramach jednej wspólnoty, a które odbierane jako zewnętrzne,

- określenie sposobów dowodzenia prawdy,

- określenie źródeł/ośrodków autorytetu potwierdzającego sądy,

- wartość aksjologiczna przypisywana pojęciom herezji i ortodoksji,

- perspektywa ortodoksji i ortopraksji, czyli myśli i działania.

\section{/// Analiza empiryczna - krótka charakterystyka poszczególnych tytułów prasowych}

\section{„Newsweek”}

Analizowane czasopisma to dwa wydania specjalne Życiowa madrosí zwierzqat „Newsweek Polska. Nauka o zwierzętach” (nr 1/2018) oraz Życie uczuciowe „Newsweek Polska. Extra o zwierzętach” (nr 3/2017). Życiowa madrość zwierzą liczy 128 stron i 27 artykułów. Dominują tam artykuły opisujące specyfikę i życie różnych zwierząt, z dużą dozą „fascynujących” (słowo z opisu wydawniczego) ciekawostek. Wyrazistą perspektywę patrzenia i oceny narzuca kategoria wydania definiująca całość jako „naukę o zwierzętach", niejako automatycznie nadająca publikacji range prawdziwości. Tytuł numeru Życiowa madrość z̧wierz̨at akcentuje główne przesłanie nakierowane na obszar rozumu, który tradycyjnie jest podstawowym wyróżnikiem ludzi. Wyraźną perspektywę - ramę interpretacyjną - nadaje krótki tekst wprowadzający do numeru. Skrytykowana jest w nim dawniejsza postawa 
wyraźnego rozdziału świata ludzi od świata zwierząt, gdy „przykładanie naszej ludzkiej miary do świata zwierzęcego uważano za błąd w sztuce" (Burda 2018: 1), a w domyśle: błąd w nauce. Świat zwierzęcych emocji prezentowany jest jako prawda wypierana w przeszłości przez ludzi, co jednak wobec współczesnych badań mózgu jest już dłużej niemożliwe.

Zerwanie z perspektywą antropocentryczną widoczne jest zarówno na poziomie przekazu treściowego, jak i w samym języku. Wniosek, że ,jesteśmy częścią rodziny zwierząt”, gdyż „nie tylko nasze ciała funkcjonuja podobnie, ale też mózgi" (tamże), prezentowany jest jako naukowo uprawomocniony, czego dowód stanowią kolejne artykuły poświęcone różnym aspektom funkcjonowania zwierząt, podkreślające m.in. ich mądrość, spryt, namysł, rozwagę, złożone funkcjonowanie społeczne, emocje (przyjaźń, miłość), zdolność empatii, dylematy moralne, uczciwość, umiejętności komunikacyjne, a nawet posługiwanie się językiem, czy wreszcie specyficzne umiejętności nieosiąalne dla ludzi. Językowo sposób opisu zwierząt jest kalką sformułowań związanych z opisem świata ludzi. Zwierzęta już na okładce występuja jako „wielcy wynalazcy”, ,,autorytety moralne, „młodzi gniewni”, „przyjaciele na śmierć i życie”.

Życie uczuciowe zwierząt, czyli drugi obok rozumu domniemany wyróżnik ludzi, było tematem wcześniejszej publikacji - Życie uczuciowe „Newsweek Polska. Ekstra o zwierzętach” (3/2017). Wnioski z lektury tego numeru sa podobne i analogiczny jest sposób prezentowania zwierząt i ich niezwykłych zdolności, o które ludzie dawniej ich nie podejrzewali lub którym przeczyli mimo „oczywistych faktów”.

Zarysowana argumentacja jest jeszcze bardziej jednoznaczna ze względu na filozofię względem zwierząt (i ludzi) wyrażoną w artykułach wprost omawiających „właściwą” relację ludzi i zwierząt. Z punktu widzenia przekazu całego wydania istotny jest zwłaszcza artykuł Wielkie serce w każdej piersi (Nowakowska 2017: 6-9) syntetyzujący przełomowe z punktu widzenia autorki momenty przemian świadomości ludzi względem zwierząt. Kluczowa postacią w historii relacji ludzi i zwierząt jest Kartezjusz, którego filozofia „brutalnie naruszyła utrzymywaną od wieków życzliwą wspólnotę wszystkich żyjących istot" i odebrała prawo do empatii względem zwierząt. „Na szczęście (dla nas wszystkich) urodził się Darwin [...], który rzucił wyzwanie kartezjuszowskim ograniczeniom”, czym zapoczątkowal prawdziwe studia nad zwierzętami prowadzące do „uznania zwierzęcych emocji i świadomości”. Od 7 lipca 2012, czyli podpisania przez naukowców zajmujących się umysłowością zwierząt „Deklaracji z Cambridge o Świadomości [...]. Mamy to na piśmie: współdzielimy emocje i myśli z braćmi 
mniejszymi. Kochamy, mamy pasje, nienawidzimy, jesteśmy lojalni, boimy się, cierpimy, cieszymy" (tamże).

Charakterystyczne jest, że w obu wydaniach mimo wspomnianego kilkukrotnie braku pewności interpretacyjnej związanej z ograniczona percepcją międzygatunkowa, wątpliwości interpretowane są na korzyść zwierząt, przeciwstawnie do krytykowanego „zaprzeczania oczywistym prawdom" dotyczącym emocji czy inteligencji zwierząt. Ten optymizm interpretacyjny widać także w komentarzu do wspomnianej wyżej Deklaracji o Świadomości, której ostrożny komunikat o nieunikalności ludzi „pod względem ośrodków neurologicznych, które budują świadomość” stanowi dowód na piśmie zasadniczej równorzędności ludzkich i zwierzęcych emocji i myśli.

Znamienne jest dostrzeżenie, co w tych opisach i zestawieniach (w dyskursie) się nie pojawia. Prawie całkowicie wyeliminowana jest perspektywa duchowości, transcendencji, religii. Zarówno ludzie, jak i zwierzęta sa istotami całkowicie biologicznymi. Słowo „dusza” pojawia się w wywiadzie z Peterem Wohllebenem i rozumiane jest po prostu jako „,[...] całość myśli, uczuć i doznań. Idąc tym tropem, nie można wykluczyć, że kruki, wieloryby, a nawet pszczoły ją mają" (Wohlleben 2017: 17). Hipotetycznie wspomniana dusza religijna, rozumiana jako istniejąca po śmierci, także nie może stanowić ludzkiego wyróżnika, a ewolucja gatunków przedstawiona jest jako oczywiste potwierdzenie takiego stwierdzenia. Ogromna zmianą dyskursu jest tu wykluczenie czy też radykalne uproszczenie duchowej perspektywy w kontekście historii nauki o człowieku.

\section{„Tygodnik Powszechny”}

Analizowane pismo zbiera w całość wydawnicza artykuły nowe oraz te opublikowane wcześniej w „Tygodniku Powszechnym”. Są one niezmiernie różnorodne: od naukowych, przez społeczno-filozoficzne, aż po gawędy i opowiastki ze wspólnego życia ludzi i zwierząt. Na 168 stronach zaprezentowany jest nie tyle świat zwierząt, ile świat ludzko-zwierzęcych relacji i przemian w kontekście osiagnięć nauk przyrodniczych, a jeszcze bardziej filozofii. Choć nie brakuje faktów i ciekawostek o zwierzętach, akcent nakierowany jest na ludzko-zwierzęce współistnienie i wzajemne odniesienia. Dyskusja toczy się mniej na poziomie praw zwierząt, a bardziej na poziomie obowiązków moralnych człowieka i jego odpowiedzialności za powierzone mu stworzenie. 
Charakterystycznym elementem argumentacji jest posługiwanie się nie tylko dowodami przyrodniczymi i nazwiskami osób naukowo zajmujących się tematyką zwierząt, lecz także oparcie się na poglądach znanych osobowości ze świata kultury, dla których zainteresowanie zwierzętami stanowi jeden $\mathrm{z}$ istotnych wymiarów ich życia osobistego. Bohaterami okładki numeru są nie tylko zwierzęta, lecz także znani ludzie, a nazwy gatunkowe zwierząt graficznie przeplatają się z nazwiskami autorów tekstów, co tworzy charakterystyczną ludzko-zwierzęcą mozaikę bohaterów.

Z punktu widzenia definicji zwierzęcia i człowieka szczególnie istotne są artykuły zgrupowane w części „Całe stworzenie”, w której rozważane są relacje między człowiekiem a innymi bytami, a teologiczna perspektywa „czynienia sobie ziemi poddanej” jest odczytywana na nowo. Nazwa części pochodzi od otwierającego artykułu autorstwa Szymona Hołowni, po czym następują artykuły katolickich ekologów ks. Stanisława Musiała i o. Stanisława Jaromiego. Wypowiedź ks. Adama Bonieckiego, redaktora seniora TP, zamyka tę część. Widoczny jest wysiłek reinterpretacji teologii chrześcijańskiej w obszarze relacji względem zwierząt. Uwaga zwrócona jest na zmiany w obszarze filozofii i teologii chrześcijańskiej i „właściwe” zinterpretowanie fragmentu Biblii „Czyńcie sobie Ziemię poddaną”. „Rozumienie biblijnego «niech panuje» $(\operatorname{Rdz} 1,26)$ jako boskiego postanowienia, że wszystko, co zostało stworzone, ma służyć dobru człowieka, odchodzi do lamusa” (Boniecki 2019: 74). Człowiek jest elementem „całego stworzenia” - szerszej całości, której źródło jest w Bogu. „Zwierzęta są na tym świecie nie tylko dla nas. Są też z nami. [...] I w zwierzętach, i w ludziach zamknięte jest Słowo, które nas stworzyło" (Hołownia 2019a: 67, 69). Pojawia się hipoteza - nadzieja, że życie wieczne nie jest zarezerwowane wyłącznie dla ludzi, choć plany Boga pozostaja tajemnica. Kluczowym wymiarem naszej bratersko-siostrzanej relacji ze zwierzętami nie jest jednak troska eschatologiczna, ale praktyczny wymiar realizacji dobra zwierząt na Ziemi. Stąd też rodzą się dylematy związane z różnego typu wykorzystaniem zwierząt, przede wszystkim jako źródła pożywienia dla ludzi, a nawet $z$ brutalnym traktowaniem szkodników.

Drugim ważnym podzbiorem artykułów światopoglądowych jest część zatytułowana „Dylemat mięsożercy”, która została poświęcona praktycznemu wymiarowi traktowania zwierząt hodowlanych i dzikich, czyli obecnie społecznie nagłośnionym zagadnieniom wegetarianizmu i weganizmu. Taka postawa oceniona jest jako docelowo najlepsza, poprawiająca jakość życia na Ziemi nie tylko zwierząt, lecz także ludzi oraz ,jest wyrazem nadziei na to, że kiedyś całe stworzenie żyć będzie bez lęku i zgodnie w od- 
nowionym przez Stwórcę świecie" (tamże: 126). Jednak nie wszyscy autorzy są wegetarianami ani też jednoznacznie do tego nie namawiają. Choć jedzenie mięsa i produktów odzwierzęcych nie jest zakazane, jest etycznie wątpliwe i może być wynikiem wewnętrznej bądź organizacyjnej niemocy, a także źródłem żalu lub nawet wstydu.

„Tygodnik Powszechny”, podchodząc do tematu relacji ludzi i zwierząt, prezentuje złożoność tego zagadnienia i nie stroni od zawiłych wyjaśnień. Wskazując na podobieństwa zwierząt i ludzi, odwołuje się do złożonych zagadnień, m.in. błędów apriorycznej kategoryzacji Kartezjusza, różnych rodzajów świadomości i poznania, właściwego wyboru nazewnictwa typu „etologia kognitywna”, „kognitywistyka porównawcza” czy „,kognitywistyka ewolucyjna" (de Waal 2019: 57), aż po dywagacje o zacieraniu się granic między pojedynczym organizmem a jego otoczeniem (Lamża 2019: 51). Doceniając wcześniej niedostrzeganą złożoność funkcjonowania zwierząt, przyznaje im wartość nie ze względu na ich inteligencję, ale sam fakt powołania przez Stwórcę do istnienia.

Dla narracji „Tygodnika Powszechnego” charakterystyczna jest niejednoznaczność pozycji człowieka względem pozostałych stworzeń. W jego narracji widoczne jest poszukiwanie kompromisu, zarówno na poziomie antropologicznym (pozycji człowieka w relacji do zwierzat), jak i na poziomie praktyki działania. Kilkukrotnie w tekstach pojawia się wskazanie, że różnica pomiędzy ludźmi a zwierzętami jest ,ilościowa, a nie jakościowa” w odniesieniu do naszych umysłów (Hohol, Baran 2019: 16), zdolności poznawczych (de Waal 2019: 57), komunikacji (Targański 2019: 111), na wielu różnych poziomach, w tym także pewnych doświadczeń duchowych (Tokarczuk 2019: 97). Ma to wskazywać na większą, niż mogłoby się wydawać, wzajemna bliskość ludzi i zwierząt, i na to, że nie jesteśmy aż tak radykalnie inni, odrębni.

Równocześnie jednak lektura artykułów pozostawia wrażenie, że pewne istotne różnice istnieja. Z jednej strony, człowiek jest częścią przyrody, z drugiej, poszukuje się jego wyróżników. Jego pozycja jest pokazana jako nadrzędna, ale nie w sposób jednoznaczny, co doskonale obrazuje jeden z tytułów - Pierwsi spośród równych (Targański 2019: 112). A jednak ludzie mają wyjątkowe zdolności i „z tych (samych) elementów składowych moga czynić nieco inny użytek” (de Waal 2019: 57). „Jesteśmy na innych szczeblach egzystencjalnej drabiny, inne są nasze role i zadania" (Hołownia 2019a: 69).

Człowiek nie jest tu zredukowany do istoty czysto biologicznej, jest w nim dusza pochodząca od Boga, ale Bożego pierwiastka i eschatologicz- 
nej nadziei nie odmawia się także zwierzętom. Zwierzęta mają nadaną im przez Boga godność, ale to człowiekowi została nadana szczególna pozycja i rola. Nie jest zakazane wykorzystywanie zwierząt przy zachowaniu troski o ich dobrostan, ale wybory związane z samoograniczeniem, „poprzestanie na tym, co wystarczy" (tamże: 127) są lepsze niż brak wstrzemięźliwości skutkujący cierpieniem zwierząt i niszczeniem przyrody. Zamiast retoryki nakazów i zakazów pojawia się argumentacja wskazująca na wagę indywidualnych decyzji, które moga przyczynić się do polepszenia sytuacji zwierząt i kondycji Ziemi.

\section{„Polonia Christiana”}

Analizowany numer dwumiesięcznika „Polonia Christiana” (71/2019) w zakresie omawianej tematyki jest objętościowo zdecydowanie mniejszy niż poprzednie tytuły. Zawiera dziewięć artykułów (w tym wywiady), które maja charakter ściśle światopoglądowy, nakierowanych na zaprezentowanie postępującej „rewolucji ekologicznej”.

Charakterystyczną cechą tego podejścia do omawiania tematyki zwierząt jest brak prezentacji samych zwierząt. Nie one są bohaterami wydania. Dyskurs o zwierzętach jest tu w istocie dyskursem humanizmu, człowieczeństwa. Omawiane artykuły przyjmuja postawę antropocentryczną: koncentruja się na człowieku i oceniają rzeczywistość wyłącznie z jego perspektywy, przywołując zwierzęta po to, by wskazać ludzką odrębność. Owa odrębność sformułowana jest bezpośrednio w wywiadzie Jerzego Wolaka z prof. Robertem de Mattei: „Różnica między człowiekiem a zwierzęciem jest oczywista - zwierzęta mają duszę zmysłową i śmiertelną, lecz brak im duszy racjonalnej i nieśmiertelnej, dlatego nie mają one ani rozumu, ani wolnej woli” (de Mattei 2019: 5). Powyższa argumentacja odwołuje się wprost do teologicznych rozważań św. Tomasza, traktowanego jako niekwestionowany autorytet, bez podejmowania dyskusji z przywoływanymi przez naukowców odkryciami dotyczącymi zdolności poznawczych i społecznych zwierząt.

Temat zmieniających się postaw względem zwierząt jest tu dowodem ideologicznych zmian, jakie nastają w świecie. Przedstawiona jest negatywna ocena współczesnej kondycji ludzkiej, w której „[d]zisiejszy człowiek staje się z dnia na dzień coraz bardziej podobny do zwierząt, ponieważ odmawia używania danego mu przez Boga rozumu” (tamże). Znaczące jest, że zgodnie z narracja „Polonia Christiana”, „,utopijna wizja kreowana przez zieloną rewolucję wcale nie ma na celu ochrony zwierząt czy środowiska

\section{/ 192 STANRZECZY 1[18]/2020}


naturalnego, ale wykreowanie zupełnie nowego człowieka" (Relich 2019b: 50) i równocześnie ma stanowić pseudoreligijna alternatywę wiary chrześcijańskiej (Jędrzejczak 2019: 60). „Współczesna pseudoekologia w postaci obrony praw zwierząt, ruchów wegańskich i zoopersonalistów stała się formą religii. Kult bogini Gai zastępuje wiarę w Boga" (Bortkiewicz 2019: 58). Ostatecznym celem ruchu ekowegańskiego jest „odwrócenie przesłania płynącego z Księgi Rodzaju. Zamiast czyńcie sobie ziemię poddana $(\operatorname{Rdz} 1,28)$ otrzymujemy zakaz ingerencji w środowisko naturalne. Panowanie nad Stworzeniem zastępuje mgliście nieokreślona «współpraca», a miejsce przesłania bądźcie płodni i rozmnażajcie się, abyście zaludnili ziemię (Rdz 1,28) zajmuje rezygnacja z dzieci dla dobra klimatu" (Relich 2019b: 52). Włączanie się w zmianę postaw względem zwierząt przedstawiane jest jako celowa „manipulacja dobrymi sercami”, „,wykorzystywanie naiwności" (Kratiuk 2019: 49) przez liderów dążących do rewolucji w porządku świata.

Język, którym posługują się autorzy, wskazuje na toczące się zmiany społeczne jako na trwającą kolejną falę rewolucji, rządzącą się rewolucyjnymi, krwawymi prawami mordu. „Na naszych oczach do głosu dochodzi ruch głoszący hasła, których realizacja może zaowocować powstaniem najbardziej zbrodniczego reżimu w dziejach ludzkości” (Doerre 2019: 52). „Aktywiści na rzecz praw zwierząt na razie obnoszą ucięte głowy świń tylko patrzeć jak sięgną po ludzkie głowy" (komentarz do zdjęcia w wywiadzie prowadzonym przez Piotra Relicha; Relich 2019a: 63). Przywoływane sa obrazy najstraszniejszych zbrodni rewolucyjnych w dziejach świata i zestawiane z owocami rewolucji światopoglądowych, z którymi współcześnie mamy do czynienia, m.in. $z$, hekatombą dzieci zabijanych w łonach matek" (Doerre 2019: 53), które na dodatek mają charakter globalny. Obecna „ekototalitarna ideologia” zagraża nam wszystkim i może „sięgnąć po zbrodnie, których jeszcze nie znamy”, związane prawdopodobnie z „programem depopulacji Ziemi” (tamże: 53-55).

W artykułach pojawiają się pozytywne odniesienia do korzystania z zasobów przyrody, w tym ze zwierząt, łowiectwo przedstawione jest jako „szacunek dla Bożego porządku, aktywna ochrona przyrody i nieoceniony wkład w tworzenie kultury" (Austyn 2019: 65). Warto przy tym podkreślić, że „Polonia Christiana” także ubolewa nad stosowaniem pewnych rozwiązań przemysłowych wiążących się z cierpieniem zwierząt i traktuje tę sytuację jako przejaw dawniejszych grzechów i wiary człowieka w swoją potęgę oraz nieumiarkowania w korzystaniu z dóbr Ziemi. Zmiana praktyk względem zwierząt (np. wegetarianizm/weganizm czy całkowity zakaz hodowli 
zwierząt futerkowych) krytykowana jest przede wszystkim ze względu na to, iż stanowi dowód dbania o zwierzęta bardziej niż o ludzi, czyli zaburzenia hierarchii wartości, podczas gdy sama poprawa losu zwierząt jest traktowana jako przejaw rozumu i godności człowieka.

\section{/// Narracje czasopism z perspektywy dyskursu herezjologicznego}

Przy porównaniu narracji omówionych czasopism pierwszymi nasuwającymi się spostrzeżeniami sa jednoznaczność i definitywność opinii prezentowana przez „Newsweek” i „Polonia Christiana” oraz wieloznaczny, niedomknięty przekaz „Tygodnika Powszechnego”. Z samej tej racji oraz ze względu na strukturę narrację tego ostatniego nie do końca można zakwalifikować jako ortodoksję, która powinna przecież stanowić jasny zespół sądów. Odpowiada za to idealnie konstrukcji pozycji heretyckich, które często raczej kwestionowały jakiś wycinek poglądów danych do wierzenia, niż jednoznacznie zaprzeczały sumie prawd wiary.

Zastanawiające jest, że gdyby zamienić ze sobą znaczną część artykułów „Newsweeka” i „Tygodnika Powszechnego”, charakter wydań nie uległby zasadniczej zmianie. Prezentują one pogłębiony (zwłaszcza w perspektywie prasy opiniotwórczej, a nie tematycznej) opis poszczególnych gatunków zwierząt, ich zaskakujących umiejętności i znakomitego przystosowania do ekosystemów, w których żyją. Oba wydawnictwa wydają się zafascynowane odkrywanymi zdolnościami zwierząt i złożonością funkcjonowania zarówno pojedynczych osobników, jak i tworzonych przez nie systemów społecznych. Szczególnie mocno zaakcentowane są cechy tradycyjnie traktowane jako ludzkie wyróżniki - związane ze samoświadomością, sposobami komunikacji, odczuwaniem i ekspresją emocji oraz funkcjonowaniem w złożonych zbiorowościach. Oba wydawnictwa traktuja postkartezjańską wizję zwierząt jako błędną i szkodliwą, choć przez wieki powszechną i często przyjmowaną bezrefleksyjnie. Kartezjusz jako ten, który poprzez porównanie zwierzęta do maszyn odebrał im prawo do odczuwania i myślenia, symbolizuje to, co w stosunku ludzi do zwierząt jest najgorsze.

Różnica pomiędzy oboma wydawnictwami widoczna jest w tekstach (lub fragmentach) światopoglądowych, które sprawiają, że odczytanie całości przekazu jest odmienne. Sposób przedstawiania świata zwierząt w „Newsweeku” jednoznacznie włącza do niego ludzi jako byty biologiczne funkcjonujące w oparciu o te same prawa i w związku z tym porównywane w sposób bezpośredni. Zniesienie hierarchii stworzenia prezentowa- 
ne jest jako jedyna prawdziwa i oczywista perspektywa postrzegania ludzi i zwierząt. Wsparcie autorytetem nauki i dogmatami ogłaszanymi przez uznane ośrodki naukowe stanowi zobiektywizowany dowód słuszności takiego podejścia. Wprawdzie ludzie przewyższaja zwierzęta w niektórych obszarach, ale jest jasno pokazane, że przegrywaja z nimi w innych. W języku dyskursu herezji-ortodoksji można powiedzieć, że czasopismo przyznaje sobie rolę głoszenia pozytywnej herezji ze świadomościa prezentowania poglądów względnie nowych i sprzecznych z poglądami większości ludzi w Polsce. Równocześnie w sposobie narracji widoczna jest nadzieja na wypieranie dawnych, nieprawdziwych sądów przez nowe, udowodnione naukowo. Prezentowanie poparcia swoich poglądów przez najważniejsze na świecie naukowe ośrodki opiniotwórcze oraz wskazywanie na rosnąca popularność tychże poglądów sugeruja walkę o zajęcie pozycji dominującej - przechodzenie z pozycji herezji na pozycję ortodoksji.

„Tygodnik Powszechny” radykalnie piętnuje przede wszystkim sposoby postępowania względem zwierząt, czyli ortopraksję, i z tej pozycji atakuje tradycyjna ortodoksję lokująca człowieka ponad zwierzętami. W prezentowanym podejściu widoczny jest jednak brak jednoznaczności i niedopowiedzenia. Z jednej strony pojawiają się artykuły pokazujące inteligencję zwierząt różniąca się od ludzkiej raczej „ilościowo niż jakościowo”. Podkreślona jest też wartość i godność zwierząt oraz generalnie stworzenia, także w oderwaniu od służebnej roli względem człowieka. Z drugiej strony nie ma jednoznacznego podważenia hierarchii stworzenia. Bóg nadal jest na pierwszym miejscu, a dalej (chyba) ludzie jako „pierwsi spośród równych” (Targański 2019: 112), lecz nie po to, by panowali nad Ziemią w sposób hedonistyczny, ale by służyli, ochraniali i umieli się zdobyć na samopoświęcenie względem „braci mniejszych” i słabszych.

W centrum ortodoksji dwumiesięcznika „Polonia Christiana” leży niezmienna od początku struktura bytów, na której opiera się natura wszechświata. Na szczycie tej struktury jest Bóg, który ja stworzył, dalej człowiek, niżej zwierzęta i rośliny, a na końcu byty nieożywione. W tej narracji osia herezji jest zatem przede wszystkim zakwestionowanie Bożego porządku i oparcie się na ludzkich sądach o rzeczywistości. Konsekwencją przyjęcia ludzkiej perspektywy myślenia jest błądzenie w kwestiach moralnych poprzez tworzenie pseudomoralnych przykazań w miejsce prawdziwej moralności. Stosunek do zwierząt jest jednym z mierników stosunku do Boga, czyli jest włączony ściśle w obszar prawd wiary. Z tego względu dyskurs ludzko-zwierzęcy płynnie łączy się w tej narracji z innymi dyskursami, które jawią się jako przeciwne Bożemu Objawieniu i cywilizacji chrześcijań- 
skiej, takimi jak radykalny ekologizm, antynatalizm czy genderyzm. „Polonia Christiana” umieszcza siebie i swoje poglądy na pozycji atakowanej odwiecznie ortodoksji walczącej z kolejnymi falami herezji.

W narracji „Tygodnika Powszechnego” współczesne cierpienie zwierzat jest do pewnego stopnia, podobnie jak w „Polonia Christiana”, skutkiem ludzkiego grzechu: chciwości, pychy, konsumpcjonizmu. Jednak kluczowym wymiarem błądzenia jest niewłaściwa interpretacja fragmentu Biblii „czyńcie sobie ziemię poddaną". Poglądy dające człowiekowi prawo dowolnego dysponowania Ziemią i jej zasobami, w tym zwierzętami, nazwane są ,aberracyjną, antropocentryczną herezją" (Hołownia 2019a: 69), niezgodną z właściwą interpretacją, w której człowiek ma być opiekunem całego Stworzenia. Stosunek do zwierząt jest przedstawiony jako bardzo istotny i przejawia się nie tylko w myśleniu, ale przede wszystkim w działaniu (ortopraksji), do którego zaliczane są m.in. wegetarianizm, weganizm, odrzucenie myślistwa, ochrona zwierząt, dbanie o ich dobrostan. Nie wynika jednak ani z praw zwierząt (narracja „Newsweeka”), ani Prawa Bożego nadającego człowiekowi pozycję nadrzędną (narracja „Polonii Christiany”), ale stanowi on pole osobistej decyzji człowieka, który dojrzewa do przyjęcia postawy zmniejszającej ilość cierpienia w świecie.

Proponowany przez „Newsweek” nowy sposób opisu świata zwierząt i włączenie w niego ludzi na tych samych prawach jest nie do pogodzenia z perspektywa prezentowaną przez „Polonię Christianę”, w której sprowadzenie człowieka do istoty czysto biologicznej jest jego animalizacja, czyli zdegradowaniem. Taki sposób postrzegania człowieka przedstawiany jest jako narzucony z zewnątrz, obcy, przybyły z Zachodu, podobnie jak wcześniej inne totalitarne ideologie. Stanowi bezpośredni atak na religijność chrześcijańska, która ma zostać zastapiona parareligijną utopią totalitarna, realizująca się na kształt rewolucji i przynosząca podobne do nich dramatyczne skutki. Ten sposób narracji przypomina mechanizm upowszechniania się „herezji kontaktowej”, czyli przejmowania poglądów od obcej grupy. Natomiast narracja „Tygodnika Powszechnego” stanowi z perspektywy „Polonii Christiany” herezję w ścisłym sensie, czyli odszczepienie w ramach jednej wspólnoty chrześcijańskiej, w której nurt heretycki stanowi groźbę wewnętrzną. Herezją w tym przypadku są już same wątpliwości i dopuszczenie pewnych myśli i rozważań, np. odnośnie do eschatologii zwierząt, a autorzy są heretykami uzurpującymi sobie prawo pozostawania wewnątrz chrześcijańskiej wspólnoty. „Polonia Christiana” jest zresztą tym czasopismem, w którym samo słowo herezja nadal jest używane w tradycyjnym kontekście. 
Konflikt podejścia „Polonii Christiany” i „Tygodnika Powszechnego" nie jest jednostronny. Da się zauważyć silnie relacyjny charakter wzajemnych oskarżeń o herezję i stawiania swoich poglądów jako ortodoksji. Z punktu widzenia „Tygodnika Powszechnego” herezja jest prezentowane przez „Polonię Christianę” podejście do relacji ludzi i zwierząt oraz jej radykalnie antropocentryczna interpretacja Biblii stawiająca człowieka w pozycji prawnie wykorzystującego dominację nad zwierzętami. „Tygodnik Powszechny" odcina się od takiego wizerunku Boga - Stwórcy i Stworzenia. Pozycja człowieka nie tylko nie daje mu prawa dysponowania Stworzeniem, ale i nakłada na niego obowiązki, z których będzie rozliczony. W tym kontekście pada fraza, że „to Stworzenie (ludzie i zwierzęta) będzie nas sądzić” (Relich 2019b: 51), stanowiąca w narracji „Polonii Christiany" dowód na całkowicie heretyckie podejście "Tygodnika Powszechnego" i demaskująca Szymona Hołownię jako heretyka walczącego z Kościołem.

Dyskurs środowisk „Tygodnika Powszechnego” i „Polonii Christiany” jest modelowym odzwierciedleniem relacji herezja-ortodoksja, zgodnie ze wspomnianą wcześniej definicją Leszka Kołakowskiego wskazującego na wspólne źródło, do którego obie narracje się odwołują (2010: 11). Obie strony oskarżają się o błędną interpretację przekazu Pisma Świętego i zarazem traktują się jako pierwotne i prawdziwe. „Tygodnik Powszechny” sugeruje, że świat zaczął się od pokojowej koegzystencji wszystkich istot i ostatecznie do niej zmierza, „Polonia Christiana” twierdzi zaś, że raj na Ziemi to utopijne mrzonki, prowadzące, jak pokazuje historia, do tragedii.

\section{/// Podsumowanie}

Relacje ludzi i zwierząt stanowia element codziennego doświadczenia i pewnego rodzaju wiedzy powszechnej, a równocześnie ze względu na intensywność przemian, jakim podlegają, coraz częściej są obszarem analiz socjologicznych. Równoległe społeczne istnienie odmiennych wzorców definiujących, kim jest człowiek w relacji do (innych) zwierząt, wyraźnie widoczne jest w mediach, gdzie funkcjonuje dyskurs o właściwym sposobie kształtowania tych relacji. Zestawienie przekazu wydawnictw opiniotwórczych o odmiennych liniach redakcyjnych, które zdecydowały się poświęcić temu zagadnieniu całe wydania, pozwoliło na uchwycenie ich wzajemnych odniesień w kategoriach ortodoksji i herezji. Wykorzystanie kategorii analitycznych zapożyczonych z teologii i użycie ich do socjologicznej analizy przekazów mediowych pomaga zrozumieć te zjawiska, przede wszystkim dzięki zwróceniu uwagi na wzajemną relacyjność poszczególnych narracji. 
Porównując sposób opisu rzeczywistości prezentowany w „Newsweeku” i „Polonii Christianie”, można mówić o funkcjonowaniu dwóch rozdzielnych wspólnot epistemicznych. Obie nawołuja do przyjęcia jednoznacznych i niepodważalnych wizji świata, choć opierają się na różnych założeniach i odwołują do całkiem nieprzystających sposobów argumentacji. „Polonia Christiana” przyjmuje pozycję „broniącej się ortodoksji”, a „Newsweek” - „pozytywnej herezji z ambicjami na przejęcie pozycji dominującej”. Między tymi wizjami świata występuje radykalny konflikt i nie widać szans na porozumienie czy choćby zbliżenie stanowisk. Obie perspektywy rozdziela całkowicie odmienna „dogmatyka” odnośnie do miejsca i roli człowieka w świecie - biologicznej istoty należącej do świata przyrody versus człowieka jako korony Bożego Stworzenia.

„Tygodnik Powszechny” zajmuje pozycję niejednoznaczną, ponieważ prezentuje etykę niedomknięta. W jego wizji człowieka można znaleźć elementy zbieżne zarówno z wizja prezentowana przez „Newsweek”, jak i „Polonię Christianę” - ludzie są „pierwszymi spośród równych”, a zwierzęta sa , „nie tylko dla nas, ale z nami”. Z „Newsweekiem” łączy go dowartościowanie zwierząt i złożoności ich funkcjonowania oraz konieczność zmiany postawy względem nich i generalnie względem Ziemi. Z „Polonią Christiana” - chrześcijańska koncepcja człowieka jako istoty cielesno-duchowej oraz wiara w Boga i jego Objawienie. Sięgając do tych samych źródeł nauczania, „Tygodnik Powszechny” stawia się na pozycjach heretyckich względem „Polonii Christiany”, które widzi w działaniach „Tygodnika Powszechnego” wspólną linię z tak krytykowanymi „ekoterrorystami”. Przyjęta metoda analizy uwidacznia istotę sporu między środowiskami odwołującymi się do tych samych katolickich korzeni, które głosząc odmienne poglądy, przyznają sobie prawo właściwego odczytania Księgi Rodzaju.

Otwarte pozostaje pytanie o to, która perspektywa ostatecznie wygra i stanie się nową ortodoksją. Jak wskazuje przykład dyskursu herezjologicznego, pierwszeństwo zyskuje nie ten, kto był pierwszy, lecz ten, kto zwyciężył w przekazie symbolicznym. 
Bibliografia:

/// Czyżewski M. 2013. Teorie dyskursu i dyskursy teorii, „Kultura i Społeczeństwo", nr 2, s. 3-25.

/// Grabowska B. 2016. Zmiana jezyka, jakim mówimy o zwierz̨tach, jako swiadectwo zmiany naszego do nich stosunku, „Poznańskie Zeszyty Humanistyczne”, nr 31, s. 31-44.

/// Granat W., red. 1973. Encyklopedia katolicka, Towarzystwo Naukowe Katolickiego Uniwersytetu Lubelskiego.

/// Harrington D. 1980. The Reception of Walter Bauer's „Orthodoxy and Heresy in Earliest Christianity” during the Last Decade, „The Harvard Theological Review", t. 73, nr 1/2, s. 289-298.

/// Herzog H. 2011. Some We Love, Some We Hate, Some We Eat, Harper Perennial.

/// Howarth D. 2008. Dyskurs, tłum. A. Gąsior-Niemiec, Oficyna Naukowa. /// Jorgensen D.W. 2017. Approaches to Orthodoxy and Heresy in the Study of Early Christianity, „Religion Compass”, t. 11, nr 7-8, e12227, https://doi. org/10.1111/rec3.12227.

/// Kaczorowski B., red. 2006 Religie świata. Encyklopedia PWN, PWN.

/// Konecki K. 2005. Ludzie i ich zwierzeta. Interakcjonistyczno-symboliczna analiza społecznego świata wtaścicieli zwierzat domowych, Scholar.

/// Kołakowski L. 2010. Herezja, Znak.

/// Köstenberger A.J., Kruger M.J. 2010. The Heresy of Orthodoxy. How Contemporary Culture's Fascination with Diversity Has Reshaped Our Understanding of Early Christianity, Crossway.

/// Latusek A., red. 2008. Wielki stownik wyrazón obcych, Krakowskie Wydawnictwo Naukowe.

/// Mamzer H. 2017. Zwierzece imiona - upodmiotowienie czy zawtasz̨zenie, „Zoophilologica. Polish Journal of Animal Studies”, nr 3, s. 163-178.

/// Myszor W. 2003-2004. Miedzy ortodoksja i herezja, „Teologia Polityczna”, nr 1, s. 133-139. 
/// O’Collins G. SJ, Farrugia E.G. SJ, red. 2002. Leksykeon teologiczny, tłum. J. Ożóg SJ, B. Żak, red. pol. H. Pietras, WAM.

/// Pawliszak P., Rancew-Sikora D. 2012. Wprowadzenie do socjologicænej analizy dyskursu (SAD), „Studia Socjologiczne”, nr 1(204), s. 5-15.

/// Press Service Monitoring Mediów. 2018. Raport medialny „Problematyka zwierzat w polskich mediach", https://psmm.pl/wp-content/uploads/2021/01/ problematyka-zwierzat-w-polskich-mediach-raport-medialny-19122018. pdf; dostęp: 10.02.2020.

/// Pręgowski M. 2016. Introduction, [w:] Companion Animal in Everyday Life. Situating Human-Animal Engagement within Cultures, red. M. Pręgowski, Palgrave Macmillan, s. 1-9.

/// Prokopiuk J. 2008. Herezja znaczy wolność, Studio Astropsychologii.

/// Rejter A. 2016. Dyskurs(y) posthumaniżmu w kontekśsie wspótczesnej komunikacji, „Poznańskie Spotkania Językoznawcze”, nr 32, s. 21-30.

/// Sobol E., red. 1995. Maty stownik jezyka polskiego PWN, Wydawnictwo Naukowe PWN.

/// Sztompka P. 2008. Życie codzৃienne - temat najnowszej socjologii, [w:] Socjologia codžienności, red. P. Sztompka, M. Boguni-Borowska, Znak, s. 15-52.

/// Vanhoutte K. 2019. A Heretical Tale about Heresy or When Words Do Matter, „HTS Teologiese Studies/Theological Studies”, nr 75(3), a5023, https:// doi.org/10.4102/hts.v75i3.5023.

/// Widok N. 2012. Ortodoksja, herezja, schįma - myjaśnienie pojeć, [w:] Ortodoksja, herezja, schiz̨ma w kościele starożytnym, red. F. Drączkowski, J. Pałucki, P. Szczur, M. Szram, M. Wysocki, M. Ziółkowska, Polihymnia, s. 15-34.

Artykuły cytowane z analizowanych źródeł

/// Austyn M. 2019. Myśliwi na celowniku, „Polonia Christiana”, nr 71, s. 64-65.

/// Boniecki A. 2019. Di்dżownico, siostro nasza, „Tygodnik Powszechny. Wydanie Specjalne", nr 3(11), s. 74.

/// Bortkiewicz P. 2019. Kult Gai zastepuje wiare w Boga, rozm. przepr. T.D. Kolanko, „Polonia Christiana”, nr 71, s. 58-60. 
/// Burda K. 2018. Jedna wielka madra rodzina, „Newsweek Polska. Nauka o zwierzętach", Życiowa madrość zwierz̨at, nr 1, s. 1.

/// de Mattei R. 2019. Cel: animalizacja, rozm. przepr. J. Wolak, „Polonia Christiana", nr 71, s. 5.

/// de Waal F. 2019. Madrzejsze niž nam sie wydaje, rozm. przepr. L. Kwiatek, B. Kucharzyk, „Tygodnik Powszechny. Wydanie Specjalne”, nr 3(11), s. $54-58$.

/// Doerre P. 2019. Zbrodnie, których jesžž nie znamy, „Polonia Christiana”, nr 71, s. 53-55.

/// Hohol M., Baran B. 2019. Myśle, więc wiem, gdzie jestem, „Tygodnik Powszechny. Wydanie Specjalne", nr 3(11), s. 15-16.

/// Hołownia Sz. 2019a. Całe stworzenie, „Tygodnik Powszechny. Wydanie Specjalne", nr 3(11), s. 67-70.

/// Hołownia Sz. 2019b. Zielono mi, „Tygodnik Powszechny. Wydanie Specjalne", nr 3(11), s. 126-127.

/// Jędrzejczak M. 2019. Ruch ekologicæny - wspótczesna pseudoreligia?, „Polonia Christiana", nr 71, s. 60-62.

/// Kratiuk K. 2019. Manipulacja dobrymi sercami, „Polonia Christiana”, nr 71, s. 49.

/// Lamża L. 2019, Śmieró wyspy, „Tygodnik Powszechny. Wydanie Specjalne", nr 3(11), s. 51-53.

/// Nowakowska M. 2017. Wielkie serce w każdej piersi, „Newsweek Polska. Ekstra o zwierzętach", nr 3, s. 6-9.

/// Relich P. 2019a. Prryroda - nowy proletariat, „Polonia Christiana”, nr 71, s. 62-63.

/// Relich P. 2019b. Zielona rewolucja, „Polonia Christiana”, nr 71, s. 50-52.

/// Targański T. 2019. Pierwsi spośród równych, „Tygodnik Powszechny. Wydanie Specjalne", nr 3(11), s. 109-112.

/// Tokarczuk O. 2019. Awantura o kury, rozm. przepr. K. Kubisiowska, „Tygodnik Powszechny. Wydanie Specjalne”, nr 3(11), s. 95-99.

/// Wohlleben P. 2017. Emocje sa jezykiem instynktów, rozm. przepr. A. Maziuk, „Newsweek Polska. Ekstra o zwierzętach”, nr 3, s. 14-17. 


\section{/// Abstrakt}

Dyskurs o ludzko-zwierzęcych relacjach w ciagu ostatnich lat istotnie nabrał na znaczeniu. Media reprezentujące różne światopoglądowo podejścia przyjęły w tym obszarze mocne i wzajemnie wykluczające się perspektywy. To społeczne zjawisko jest okazją do poszukiwania nowego teoretycznego podejścia do analizy socjologicznej.

Artykuł ma charakter teoretyczno-empiryczny. W warstwie teoretycznej pokazuje, jak kategorie herezji i ortodoksji można wykorzystać, poza obszarem ścisłej teologii, do socjologicznego badania zjawisk społecznych. Przedstawiony zarys dyskursu herezjologicznego wykorzystany jest do wskazania nowych wymiarów wyjaśniających zmieniające się relacje ludzi i zwierząt. Uwaga nakierowana jest na prześledzenie sposobów przedstawiania siebie i własnej doktryny jako ortodoksji, a oponentów i głoszonych przez nich doktryn jako heretyków i herezji.

W pracy analizowane są numery specjalne czasopism opiniotwórczych poświęcone tematyce zwierząt („Newsweek Polska”, „Polonia Christiana”, „Tygodnik Powszechny”), opublikowane w latach 2017-2019. Na podstawie materiału empirycznego widać, jak relacyjność wpisana w parę pojęć herezja-ortodoksja pozwala wydobyć istotę sporu dotyczącego „właściwego" sposobu postrzegania zwierząt i kształtowania ludzko-zwierzęcych relacji. Takie podejście pozwala pogłębić analizę współwystępowania odmiennych poglądów o aspekty ich wzajemnych odniesień oraz prześledzić proces uznawania ich za prawdziwe lub fałszywe. Uwzględnienie dyskursu herezjologicznego umożliwia lepsze zrozumienie dynamiki rywalizacji o zwycięstwo w przekazie symbolicznym.

Słowa kluczowe:

herezja, ortodoksja, relacje ludzi i zwierząt, dyskurs, analiza prasowa

\section{/// Abstract}

\section{Orthodoxy and Heresy in the Human-Animal Relationship}

The discourse on the human-animal relationship has recently received wider attention in Poland. Periodicals with different ideological backgrounds have taken strong and mutually exclusive positions. This social phenomenon provides an opportunity to apply a novel theoretical approach to sociological analysis. 
In regard to theory, this paper shows how categories of heresy and orthodoxy can be applied beyond theology. The proposed outline of Christian heresiological discourse is used to indicate aspects worth considering in analyses of the changing relationships between humans and animals. In particular, the focus is on how people present themselves and their doctrine as orthodox while viewing their opponents as heretics holding heretical principles.

The empirical analysis covers the special issues on animals published by influential Polish periodicals between 2017 and 2019. These periodicals (Newsweek Polska, Polonia Christiana, and Tygodnik Powszechny) were chosen for their different world-views. The paper demonstrates how relationality, inherent in the heresy-orthodoxy pair of concepts, allows to bring out contradictory narratives regarding the postulated way of perceiving animals and shaping human-animal relationships. The paper provides an in-depth analysis of the present conflicting views and spill-over effects, as well as of the dynamic process of recognising these views as true or false. Considering the heresiological discourse makes it possible to better understand the competition for cultural dominance.

Keywords:

heresy, orthodoxy, human-animal relationship, discourse, press analysis

/// Anna Dietl - doktorantka w Instytucie Stosowanych Nauk Społecznych Uniwersytetu Warszawskiego. Interesuje ja problematyka socjologicznej analizy relacji ludzi i zwierząt. Zanim rozpoczęła pracą naukową, przez ponad 10 lat zajmowała się budowaniem strategii komunikacyjnych i analizą mediów.

ORCID: https://orcid.org/0000-0001-7005-8804

E-mail: anna@dietl.pl 